\title{
MIĘDZY „JARZMEM FANARIOCKIM” A ,JARZMEM JEZUICKIM”. POLEMIKI WOKÓŁ BUŁGARSKIEJ KWESTII CERKIEWNEJ MIĘDZY PERIODYKAMI „BUŁGARIA” A „DUNAJSKI ŁABĘDŹ” W LATACH 1859-1861
}

\author{
KRZYSZTOF POPEK
}

\begin{abstract}
Between the "Phanariote Yoke” and the „Jesuitical Yoke”. The 1859-1861 polemics between "Bulgaria" and "The Danubian Swan" journals concerning the issue of the Bulgarian Church.

At the turn of 1850 s and 1860s there was a serious discussion inside the Bulgarian Church Movement, which had fallen apart into four parties: national, pro-Turkish moderates, pro-Russian moderates and pro-Uniate. One of the most fervent debates took place between the journals "The Danubian Swan" (edited by Georgi Sava Rakovski, connected with the national party the Church Movement) and "Bulgaria" (published by the leader of pro-Uniate party Dragan Tzankov). The discussions focused on the topics pivotal for the Bulgarian national case: the relation of the Church Movement to the Ottoman Empire, the Patriarchate of Constantinople, the Catholic Church and the Great Powers (especially Russia and France), the problem of the Bulgarian cultural model, the medieval heritage and Christian dogmas. One of those topics concerned the relation of the Church movement to the Ottoman Empire - in general both journals declared loyalty to the Sultan, but the problem mainly concerned the Turkish censorship. "Bulgaria" and "The Dunabian Swan" agreed that the Patriarchate of Constantinople is the main enemy of Bulgarian interests. Liberating the Bulgarian Church from Greeks was their primary goal. Tzankov wanted to realize this goal in cooperation with the Catholic Church, for Rakovski, instead, the Church Union would lead to the new enslavement of the Bulgarians, who would fall under the "yoke of Jesuits". That problem was also connected with the search for an ally between the Great Powers: "Bulgaria" wanted to cooperate with France, which was the main patron of Catholicism in the World, whereas "The Dunabian Swan" tried to gain Russian support. The activists of the Church Movement realized that the Union will have a significant impact on the future of the Bulgarian culture. Tzankov was a proponent of the modernization of the Bulgarian society according to Western standards. Rakovski warned that the Union will be the beginning of the collapse of the Bulgarian nation and a betray of its age-old connection with the Orthodox Church. They proved these visions with historical examples - during the discussion the editor of "Bulgaria" created an alternative and false version of the Medieval history of Bulgaria, in which he tried to prove the existence of deep relations between Bulgarians and the Catholic Church. Another important part of the discussion between the journals revolved around Christian dogmas and was based on the old polemics about dogmas lasting since the 9th century between the Western and Eastern Christianity. The arguments used in the articles about the Church Movement by Rakovski and Tzankov only very rarely had a rational character, they were usually based on emotions, stereotypes and the Bulgarian sense of pride.
\end{abstract}

Autor: Krzysztof Popek, Uniwersytet Jagielloński, Wydział Historyczny, Instytut Historii, Zakład Historii Powszechnej Nowoczesnej, ul. Gołębia 13, 31-007 Kraków, Polska-Poland, popek.kj@gmail.com

Słowa kluczowe: Bułgaria, Ruch cerkiewny, Unia kościelna, XIX wiek, Bułgarskie odrodzenie narodowe Keywords: Bulgaria, the Church Movement, the Church Union, 19th Century, Bulgarian Revival

Balcanica Posnaniensia. Acta et studia, XXII/2, Poznań 2015, Wydawnictwo Instytutu Historii UAM, pp. 55-74, ISBN 978-83-63047-88-7, ISSN 0239-4278. Polish text with a summary in English. 
W XIX wieku Bułgarzy dążyli do uzyskania niepodległości spod władzy osmańskiej różnymi sposobami. Cześć bułgarskich działaczy stosowało metody radykalne: współpracowali z Rosjanami w czasie wojen turecko-rosyjskich, rozwijali działalność partyzancką (tzw. czety), tworzyli komitety rewolucyjne, organizowali powstania oraz bunty. Inną taktykę przyjęli umiarkowani działacze ruchu narodowego, tzw. ruchu cerkiewnego, który na pozór miał charakter wyłącznie religijno-instytucjonalny. Ich starania o uniezależnienie Cerkwi bułgarskiej od patriarchatu Konstantynopola należy traktować jako walkę o uznanie Bułgarów za odrębny millet (wspólnotę religijną), co było równoznaczne z uzyskaniem autonomii administracyjno-oświatowej oraz podmiotowości politycznej w ramach Imperium Osmańskiego ${ }^{1}$. Wprawdzie działaczy cerkiewnych łączył wspólny cel, jednak szybko doszło do burzliwych sporów o sposoby jego realizacji. Po wojnie krymskiej wewnętrzne tarcia doprowadziły do rozpadu ruchu na kilka, zwalczających się stronnictw: narodowe (dążące do uzyskanie pełnej niezależności cerkiewnej, która stanowiłaby podstawę do utworzenia w przyszłości państwa bułgarskiego), dwa umiarkowane (rusofilskie i turkofilskie) oraz unickie (łączące realizację celów narodowych z zawarciem unii kościelnej z Rzymem) ${ }^{2}$. Na przełomie lat pięćdziesiątych oraz sześćdziesiątych XIX wieku główną osią polemik między stronnictwami ruchu była perspektywa współpracy z Kościołem katolickim $^{3}$. Jedna z najważniejszych dyskusji wokół przyszłości kwestii cerkiewnej rozgorzała między prounicką „Bułgarią”, wydawaną przez Dragana Cankowa, a sympatyzującym ze stronnictwem narodowym „Dunajskim Łabędziem”, którego redaktorem był Georgi Sawa Rakowski.

${ }^{1}$ И. Тодев, Батак 1876 - мит или история. Текстове по Българско Възраждане, Тангра ТанНакРа, София, 2010, s. 128-136; D. Stamatopoulos, From Millets to Minorities in the 19th Century Ottoman Empire: an Am-biguous Modernization, w: Citizenship in Historical Perspective, red. S. G. Ellis, G. Hálfadanarson, A. K. Isa-acs, Pisa University Press, Piza, 2006, s. 253-273; Więcej o bułgarskim ruchu cerkiewnym zob. 3. Маркова, Българското иърковно-национално движение до Кримската война, БАН, София, 1976; Т. Жечев, Българският Великден или страстите български, Издателство „Захари Стоянов“", София, 2007; В. Бонева, Българското иърковнонационално движение 1856-1870, За буквите, София, 2010; W języku polskim: K. Popek, ,Mała kwestia wschodnia”. Aspekty polityczne dziewiętnastowiecznego bułgarskiego ruchu cerkiewnego, „Studenckie Zeszyty Naukowe Instytutu Filologii Słowiańskiej UJ", 3, 2013, 1, s. 73-88.

${ }^{2}$ Obok zaprezentowanego podziału powstały także inne klasyfikacje stronnictw ruchu cerkiewnego po wojnie krymskiej. Jerzy Skowronek, Ludwik Widerszal czy Georgi Minczew wymieniają trzy obozy (,starzy”, „młodzi”, ruch unicki) i jest to podział ogólnie przyjmowany w historiografii bułgarskiej. Jednak bardziej rozbudowana typologia zaproponowana przez Nikołaja Genczewa wydaje się najbardziej oddawać specyfikę ruchu cerkiewnego. Zob. Н. Генчев, Българското Възраждане, София 1995, 309-310; Por. L. Widerszal, Bułgarski ruch narodowy 1856-1872, Towarzystwo Naukowe Warszawskie, Warszawa, 1937, s. 106; J. Skowronek, M. Tanty, T. Wasilewski, Historia Słowian południowych i zachodnich, PWN, Warszawa, 1988, s. 362; G. Minczew, ,, Watykańscy szpiedzy” i zdrajcy narodu w XIX wieku w Butgarii, w: Obraz zdrajcy i szpiega w kulturach słowiańskich, red. T. Dąbek-Wirgowa, A. Makowiecki, Antyk, Warszawa, 1999, s. 108-109.

${ }^{3}$ Szczegółowo na temat bułgarskiego ruchu unickiego zob. K. Popek, ,Idea zrodzona z rozpaczy“. Rola ruchu unickiego w butgarskim odrodzeniu narodowym, „Balcanica Posnaniensia. Acta et studia”, 21, 2014, s. 103-120. 
W niniejszym artykule zostanie przeprowadzona analiza głównych problemów dotyczących bułgarskiej kwestii cerkiewnej podejmowanych na łamach dwóch tygodników odrodzeniowych z okresu 1859-1861: „Bułgarii” oraz „Dunajskiego Łabędzia", które posłużą do rekonstrukcji programów politycznych ruchu unickiego oraz stronnictwa narodowego ruchu cerkiewnego. W literaturze naukowej kwestią polemik cerkiewnych w prasie odrodzeniowej najszerzej zajmowali się Tonczo Żeczew oraz Georgi Minczew, jednak skupiali się oni na innych aspektach tej problematyki. Pierwszy z wymienionych badaczy koncentrował się na roli Konstantynopola jako centrum nie tylko ruchu cerkiewnego, ale i życia polityczno-społecznego Bułgarów na przełomie lat pięćdziesiątych oraz sześćdziesiątych XIX wieku ${ }^{4}$, drugi zaś na roli stereotypów w tych dyskusjach ${ }^{5}$. Analizowane numery czasopism dostępne są w Bułgarskim Archiwum Historycznym w Sofii, a także w formie elektronicznej na stronie internetowej Biblioteki Narodowej im. św. św. Cyryla i Metodego w Sofii ${ }^{6}$.

Tygodnik „Bułgaria. Gazeta o sprawach bułgarskich“ („България. Вестник за българскити интереси“) był wydawany z pewnymi przerwami od kwietnia (marca starego stylu) 1859 roku do marca 1863 roku, został założony przez lidera ruchu unickiego Dragana Cankowa ${ }^{7}$ oraz działacza odrodzeniowego związanego z miastem Burgas Dimitra Brakałowa ${ }^{8}$. Na jego łamach publikowali nie tylko zwolennicy przyjęcia grekokatolicyzmu przez Bułgarów, ale także lazaryści z klasztoru San Benedetto w Konstantynopolu, przede wszystkim ojciec Jean-Claude Faverial. Tygodnik był uznawany za organ Kongregacji Propagandy Wiary w Bułgariii. W okresie szczytu popularności ruchu unickiego, czyli w latach 1859-1861, periodyk cieszył się dużą poczytnością, czego dowodem była potrzeba zwiększenia nakładu ${ }^{10}$ - rozprowadzano

${ }^{4}$ T. Жечев, op. cit.; G. Simeonova-Konach, ,,Pascha Butgarska“, Unia i jej konteksty konstantynopolitańskie w badaniach prof. Tonczo Żeczewa, w: Chrześcijański Wschód i Zachód. Formy dialogu, wzory kultury, kody pamięci, red. W. Jóźwiak, I. Lis-Wielgosz, Wydawnictwo „Pro”, Poznań, 2012, s. 33-51.

5 G. Minczew, op. cit.; Г. Минчев, Богословът Георги Сава Раковски: Отговор Чокърляну една (по)забравена брошура на комплексия войвода, w: Wielkie mity narodowe Stowian, red. A. Gawarecka, A. Naumow, B. Zieliński, Uniwersytet im. Adama Mickiewicza w Poznaniu, Poznań, 1999, s. $149-163$.

${ }^{6}$ Zob. http://www.nationallibrary.bg/cgi-bin/e-cms/vis/vis.pl?p=0038 [dostęp: 03.12.2015].

${ }^{7}$ Zob. М. Ковачева, Драган Цанков: общественик, политик, дипломат до 1878, Наука и изкуство, София, 1982; С. Чилингиров, Драган Цанков, w: Български писатели. Живот-творчествоидеи, т. 2, ред. М. Апнаудов, София, Факел, 1929, s. 174-193; М. Узунова, Драган Цанков- неспокоен дух на гранииата на две епохи, „LiterNet”, 100, 2008, 3, http://liternet.bg/publish22/m_uzunova/dr_ cankov.htm, [dostęp: 12.09.2015].

${ }^{8}$ Dimityr Brakałow zasłynął jako wieloletni burmistrz Burgasu (1885-1899). W latach 1858-1867 przebywał w Konstantynopolu, gdzie uczęszczał do francuskiego liceum katolickiego w dzielnicy Galata i rozpoczął współpracę z Draganem Cankowem. Zob. С. Пейков, Забравените кметове на Бургас: Димитър Тодоров Бракалов, www.morskivestnik.com/mor_kolekcii/kmetowe/zabrkmbsdim.html, [dostęp: 12.09.2015].

${ }^{9}$ Część artykułów podpisanych przez Cankowa była autorstwa lazarystów. Były one tłumaczone przez niego z języka francuskiego na bułgarski. Zob. Патриарх Кирил, Принос към униатството в Македония след Освободителната война (1879-1895), Синодално издателство, София, 1968, s. 112 .

10 „България“, r. 1, nr 23, 29.08.1859, s. 1. 
go wśród diaspory w stolicy Imperium Osmańskiego, w bułgarskich miastach (m.in. Tyrnowie, Sofii, Szumenie, Warnie, Burgasie) i wsiach (m.in. Kałoferze, Dupnicy, Łoweczu, Pazardżiku), a także wśród środowisk emigracyjnych na ziemiach rumuńskich (Tulcza, Izmaił, Braiła) ${ }^{11}$. „Bułgaria“, jako organ stronnictwa unickiego, skupiała się na tematyce związanej z bułgarską walką o niezależność kościelną oraz na polemikach z pozostałymi nurtami ruchu cerkiewnego i greckimi hierarchami. W każdym numerze informowano także o sytuacji w Europie (działy „Przegląd polityczny“ oraz „Różne tematy i nowiny“) i nowościach wydawniczych, a także publikowano listy nadsyłane przez czytelników. Początkowo gazeta wyrażała swoje poparcie dla zawarcia unii z Rzymem w sposób zawoalowany, skupiając się na krytyce patriarchatu Konstantynopola oraz wpływów rosyjskich wśród Bułgarów czy na propagowaniu rozwoju szkolnictwa oraz kultury na wzór zachodni. Zawierała jednak pewne treści prokatolickie, które z całą mocą zostały ujawnione dopiero w lipcu 1859 roku, czyli po zawarciu unii kościelnej w Kukuszu ${ }^{12}$.

Cankow założył „Bułgarię“ nie tylko w celu szerzenia idei unii wśród Bułgarów, ale przede wszystkim by prowadzić polemiki z innymi nurtami ruchu cerkiewnego, które uznawał za szkodliwe dla bułgarskiej sprawy narodowej. Początkowo krytykował głównie umiarkowanych rusofilów, związanych z „Gazetą Carogrodzką“ („Цариградски вестник”, 1848-1862), jednak w październiku 1860 roku do roli głównego organu antyunickiego wyrósł „Dunajski Łabędź“ („Дунавски лебед“), który był wydawany w Belgradzie do grudnia 1861 roku $^{13}$. Redaktorem naczelnym czasopisma był Georgi Sawa Rakowski, kluczowa figura bułgarskiego odrodzenia narodowego i jeden z najzacieklejszych przeciwników unii ${ }^{14}$. Jego niechęć do katolicyzmu była związana nie tylko z panującymi stereotypami wśród ludności prawosławnej i przywiązaniem do tradycyjnego modelu kultury bułgarskiej, ale i ze wcześniejszymi doświadczeniami ze współpracy z Polakami w latach czterdziestych oraz pięćdziesiątych XIX wieku ${ }^{15}$. Był przekonany o antyprawosławnej działalności emigracji polskiej

11 „България“, r. 2, nr 77, 7.09.1860, s. 1.

12 Български периодичен печат 1844-1944, т. 1, ред. Д. Иванчев, Наука и изкуство, София, 1966, s. 116-117; Do unii kościelnej w Kukuszu doszło wyniku konfliktu miejscowej ludności z greckim władyką polenińskim Meletiosem. W przeciwieństwie do unii z 1860 roku miała ona wyłącznie lokalny charakter. Zob. K. Popek, ,Idea zrodzona z rozpaczy”..., s. 105-107.

13 Do pierwszej próby wydawania „Dunajskiego Łabędzia“ doszło w 1857 roku w Nowym Sadzie, jednak z powodu braku środków projekt został wstrzymany. Zob. „Дунавски лебед “, 1857. (brak numeru, rocznika i daty dziennej). Było to typowe zjawiska dla początków prasy odrodzeniowej. Pierwszy bułgarski periodyk „Umiłowanie słowa“ („Любословие“) ograniczył się do jednego numeru z 1842 roku, a został wznowiony dopiero w latach 1844-1846. Zob. A. Nowosad, Władza i media w Bułgarii, WUJ, Kraków, 2008, s. 77-81.

14 Więcej o Georgim Sawie Rakowskim zob. V. Traikov, Georgi Rakovski A Short Biography, Sofia Press, Sofia, 1977.

${ }^{15} \mathrm{~W}$ drugiej połowie lat czterdziestych XIX wieku doszło do krótkotrwałej współpracy między Hôtelem Lambert a działaczami cerkiewnymi, wśród których był Rakowski. Bułgarzy dosyć szybko z niej zrezygnowali, gdy okazało się, że Polacy nie są w stanie skutecznie wspierać ich interesów przed Wysoką Portą. W okresie wojny krymskiej Rakowski rozpoczął współpracę z Sadykiem paszą (Michałem Czajkowskim) - powstał wówczas projekt skorelowania planów rewolucjonistów bułgarskich z działa- 
w Turcji, która rzekomo chciała doprowadzić do katolicyzacji Bułgarii, a następnie przeistoczenia jej w nowe Królestwo Polskie ${ }^{16}$. Wydawany przez niego tygodnik „Dunajski Łabędź“, podobnie jak „Bułgaria“, miał zasięg ogólnonarodowy - docierał do czytelników z ziem bułgarskich i macedońskich (Płowdiw, Ruszczuk ${ }^{17}$, Swisztow, Bitola), największych metropolii Imperium Osmańskiego (Konstantynopol, Saloniki) oraz diaspor w Serbii (Belgrad) i w księstwach rumuńskich (m.in. Bukareszt, Tulcza, Gałacz) ${ }^{18}$. Na łamach „Dunajskiego Łabędzia“ poruszano przede wszystkim problematykę ruchu cerkiewnego, ale także informowano o sytuacji w Europie oraz publikowano fragmenty dzieł bułgarskich pisarzy i poetów. Przez cały okres wydawania periodyk konsekwentnie krytykował zarówno patriarchat, jak i ruch unicki ${ }^{19}$.

Na łamach „Bułgarii“ oraz „Dunajskiego Łabędzia“ miała miejsce najważniejsza polemika na temat kwestii zawarcia unii z Kościołem katolickim, która stanowiła równocześnie konfrontację programów stronnictwa unickiego oraz narodowego. Dyskusje toczone były wokół stosunku ruchu cerkiewnego do Imperium Osmańskiego, patriarchatu Konstantynopola, Kościoła katolickiego oraz mocarstw (przede wszystkim Rosji oraz Francji), rozwoju kultury bułgarskiej, dziedzictwa średniowiecznego oraz dogmatów chrześcijańskich.

„Bułgaria“ stała na stanowisku lojalistycznym wobec władzy tureckiej. Cankow wielokrotnie deklarował wierność sułtanowi Abdülmecidowi I (od czerwca 1861 roku Abdülazizowi), uznając go nie tylko za pełnoprawnego władcę, ale i opiekuna ludności bułgarskiej ${ }^{20}$. Czasopismo - wzorem akcji działaczy cerkiewnych podejmowanych od połowy lat czterdziestych XIX wieku - zachęcało do wysyłania petycji z prośbą o realizację postulatów ruchu do padyszacha, który był prezentowany jako zwolennik unii oraz przyznania Bułgarom niezawisłości kościelnej pod zwierzchnictwem papiestwa ${ }^{21}$. Na tej postawie jednak nie można uznać Cankowa za turkofila $^{22}$. Tego typu deklaracje podyktowane były chęcią uzyskania konkretnych korzyści od Wysokiej Porty, przede wszystkim uznania przyszłej wspólnoty bułgarskich

niami formacji kozaków sułtańskich, jednak szybko okazało się, że interesy tych środowisk były sprzeczne. Zob. В. Смоховска-Петрова, Неофит Бозвели и българският изърковен въпрос. Нови данни из архивите на Адам Чарториски, БАН, София, 1964, passim; J. Skowronek, Sprzymierzeńcy narodów bałkańskich, PWN, Warszawa, 1983, passim; Idem, Polacy jako partnerzy polityczni na Bałkanach w latach trzydziestych-pięćdziesiatych XIX w., w: Wielka Emigracja i sprawa polska a Europa (1832-1864), red. S. Kalembka, Wydawnictwo UAM, Toruń, 1971, s. 89-105.

16 Z. Klejn, Próby stworzenia polskich przyczółków militarno-politycznych na Bałkanach $w$ XIX w., „Studia z Dziejów Rosji i Europy Środkowo-Wschodniej”, 40, 2005, s. 11-12.

17 Obecnie: Ruse.

18 „Дунавски лебед“, r. 1, nr 1, 1.09.1860, s. 1.

19 Български периодичен печат..., т. 1, s. 263-264.

20 „България“, r. 1, nr 1, 22.03.1859, s. 1.

21 „България“", r. 1, nr 22, 22.08.1859, s. 1-2.

$22 \mathrm{Z}$ racji drukowania tygodnika w stolicy imperium wszystkie teksty publikowane na łamach,,Bułgarii” podlegały surowej cenzurze, co Cankow odczuł wcześniej na własnej skórze (w 1850 roku władze osmańskie uniemożliwiły mu otworzenia drukarni w Swisztowie). Zob. W. Jóźwiak, Piśmiennictwo polskiej misji unickiej na terenie Bułgarii w drugiej połowie XIX wieku, Alleluja - Wydawnictwo Zmartwychwstańców, Kraków, 2008, s. 63. 
grekokatolików za oddzielny millet (co zostało osiągnięte w czerwcu 1861 roku) ${ }^{23}$. Tymczasem „Dunajski Łabędź“ był wydawany w Belgradzie, znajdującym się na obszarze Księstwa Serbii i nie podlegał bezpośrednio surowej cenzurze władz osmańskich. Mimo to krytyka władz tureckich była w nim wyważona, pozostająca na marginesie rozważań o kwestii cerkiewnej, co mogło być związane z zależnością Belgradu od Konstantynopola. Władze serbskie nie mogłyby pozwolić na propagowanie na obszarze państwa radykalnych haseł wymierzonych $\mathrm{w}$ ich zwierzchnika w osobie sułtana. Stosunek do Turcji pozostaje więc na łamach „Dunajskiego Łabędzia” niejednolity. $\mathrm{Z}$ jednej strony w tekstach Rakowskiego pojawiają się zarzuty skierowane przeciwko ruchowi unickiemu oraz misjonarzom katolickim o bycie marionetkami w rękach władz osmańskich, które w ten sposób dążyły do skłócenia narodu bułgarskiego ${ }^{24}$, a z drugiej redaktor wyrażał nadzieje związane z mediacją Wysokiej Porty w toczonych wówczas negocjacjach bułgarsko-greckich, celem których było ugodowe rozwiązanie sporu ${ }^{25}$. Jednak poglądy Rakowskiego, głoszone na łamach „Dunajskiego Łabędzia”, daleko odbiegały od przekonań radykała, bezkompromisowego w walce o wyzwolenie Bułgarów spod jarzma tureckiego, jak zazwyczaj przedstawia go historiografia ${ }^{26}$.

Cankow oraz Rakowski reprezentowali tak samo wrogi stosunek do instytucji patriarchatu Konstantynopola, konsekwentnie nazywanego przez nich „fanariockim“. Każdy z nurtów ruchu cerkiewnego upatrywał w Grekach główne źródło problemów narodu bułgarskiego: braku szkolnictwa w języku narodowym, uniemożliwiania odprawiania liturgii cerkiewno-słowiańskiej, zubożenia materialnego wynikającego z polityki fiskalnej władyków oraz pozbawienia podstawowych praw politycznych ${ }^{27}$. Na łamach „Dunajskiego Łabędzia“ pojawiały się nawet zarzuty o wynajmowanie przez hierarchów kościelnych skrytobójców, z których rąk mieli być mordowani działacze cerkiewni z Tyrnowa, Karłowa i Starej Zagory ${ }^{28}$. Jednak o ile Rakowski popierał negocjacje prowadzone na bułgarsko-greckich soborach oraz dopuszczał scenariusz rozwiązania kwestii cerkiewnej w porozumieniu z patriarchatem ${ }^{29}$, Cankow był w tej kwestii bezkompromisowy, nazywając pertraktacje z hierarchami zdradą naro-

${ }^{23}$ K. Popek, ,Idea zrodzona z rozpaczy”..., s. 113.

24 „Дунавски лебед“, r. 1, nr 7, 27.10.1860, s. 2-3.

25 „Дунавски лебед“, r. 1, nr 14, 13.12.1860, s. 1; „Дунавски лебед“, r. 1, nr 15, 20.12.1860, s. 1; Więcej o soborach bułgarsko-greckich w tym okresie zob. К. Иречек, История на българите: с поправки и добавки от самия автор, Наука и изкуство, София, 1978, s. 582; L. Widerszal, op. cit., s. $116-118$.

26 Por. Г. С. Раковски, Туркса Европа, 18 април 1861 г., w: Idem, Съчинения, т. 2: Публицистика, Български писател, София, 1983, s. 275; V. Traikov, op. cit., passim; T. Dąbek - Wirgowa, Historia literatury butgarskiej, Ossolineum, Wrocław, 1980, s. 91-95.

27 „Дунавски лебед“, r. 1, nr 4, 6.10.1860, s. 1; „Дунавски лебед“, r. 1, nr 12, 29.11.1860, s. 3-4; „България“, r. 1, nr 1, 22.03.1859, s. 3; „България“, r. 1, nr 2, 1.04.1859, s. 1-3; „България“, r. 1, nr 3, 11.04.1859, s. 3; „България“, r. 1, nr 8, 9.05.1859, s. 1-3; Р. Детрез, „Туриите със сила, гъриите с книга“. Митът за двойното робство, „Либерален преглед”, 2012, 2, s. 454-470.

28 „Дунавски лебед“, r. 1, nr 11, 22.11.1860, s. 1.

29 „Дунавски лебед“", r. 1, nr 15, 20.12.1860, s. 1. 
dową ${ }^{30}$. Ruch unicki uważał, że jakakolwiek zależność Bułgarów od hierarchii greckiej doprowadzi do statusu quo i pod zmienioną formą umocni ,jarzmo fanariockie“ nad ludnością bułgarską, a z kompromisu skorzystają jedynie czorbadżi ${ }^{31}$.

Główną osią polemik toczonych na łamach „Bułgarii“ oraz „Dunajskiego Łabędzia“ był stosunek do Kościoła katolickiego. Według zwolenników unii, Rzym mógł spełnić wszystkie postulaty ruchu cerkiewnego - niezależną Cerkiew z zagwarantowaną cerkiewnosłowiańską liturgią, edukację w języku bułgarskim oraz zakończenie zwierzchnictwa patriarchatu Konstantynopola nad Bułgarami ${ }^{32}$. Cankow odwoływał się w tym przypadku do doświadczenia ormiańskich unitów zamieszkujących Imperium Osmańskie, którzy po upadku Konstantynopola w 1453 roku otrzymali własny millet wraz ze wszystkimi przywilejami z tym związanymi. Rzym gwarantował Kościołowi ormiańskiemu ${ }^{33}$ liturgię oraz szkolnictwo w języku narodowym, a także obiecał szanować tradycje związane z obrządkiem wschodnim. Niezależna narodowa hierarchia ormiańska funkcjonowała przez wieki i była wyłaniana przez wiernych wspólnoty grekokatolickiej ${ }^{34}$. Jako przykład dobrej sytuacji materialnej ormiańskich unitów „Bułgaria” podawała liczne kościoły w Konstantynopolu, wybudowane dzięki finansowaniu płynącemu ze Stolicy Apostolskiej oraz państw katolickich ${ }^{35}$. Cankow starał się wykazać, że podobnymi przywilejami w państwie Osmanów cieszyli się także koptyjscy oraz maroniccy grekokatolicy ${ }^{36}$. Stawiał on te wspólnoty za wzór dla Bułgarów, samą unię przedstawiał jako jedyną realną drogą do rozwiązania kwestii cerkiewnej, a papiestwo oraz katolików jako sojuszników, którzy chcieli zaoferować Bułgarom utworzenie niezależnej hierarchii ${ }^{37}$. Tymczasem „Dunajski Łabędź“ w dużej mierze został założony właśnie w celu zwalczania idei unii. Rakowski przekonywał swoich czytelników, że podległość narodów katolickich wobec Rzymu funkcjonuje na takich samych zasadach, co Bułgarów wobec ,patriarchatu fanariockiego“ - instytucje te miały wymagać ślepego posłuszeństwa, prowadzić politykę nadmiernego fiskalizmu wobec wiernych, ale przede wszystkim być siłami antynarodowymi, narzucającymi niezrozumiałe dla ludu łacinę czy grekę w kościołach i szkołach ${ }^{38}$. Periodyk

30 „България“, r. 1, nr 5, 25.04.1859, s. 1.

31 „България“, r. 1, nr 8, 16.05.1859, s. 2; „България““, r. 1, nr 20, 8.08.1859, s. 1; L. Widerszal, op. cit., s. 110.

32 „България“, r. 1, nr 16, 11.07.1859, s. 3; „България“, r. 1, nr 17, 18.07.1859, s. 1-2.

33 Chodzi o Kościół katolicki Obrządku Ormiańskiego, którego nie należy mylić z Apostolskim Kościołem Ormiańskim, należącym do wschodnich Kościołów chrześcijańskich.

34 Cankow szczegółowo opisał procedury powoływania biskupów ormiańskich zob. „България“, r. 1, nr 39, 19.12.1859, s. 1-2; „България““, r. 1, nr 40, 24.12.1859, s. 1.

35 „България“", r. 1, nr 39, 19.12.1859, s. 1.

36 „България“", r. 1, nr 32, 31.10.1859, s. 1.

37 „България“", r. 1, nr 27, 25.09.1859, s. 1.

38 „Дунавски лебед“, r. 1, nr 3, 29.09.1860, s. 2-4; Rakowski udowadniał antynarodowy charakter patriarchatu Konstantynopola na przykładzie jego stosunku do greckiego powstania narodowego (1821-1829), w czasie którego na wszystkich uczestników zrywu została nałożona ekskomunika. Spór ten był kontynuowany po utworzeniu niepodległego Królestwa Grecji - w 1833 roku synod w Nauplion zadecydował o separacji Kościoła greckiego patriarchatu w Konstantynopolu, nie podejmując nawet prób negocjacji z hierarchami. Egzemplifikacją konfliktu między Atenami a patriarchatem mogą być słowa 
wielokrotnie podkreślał, że przyjęcie unii nie zmieni położenia ludności bułgarskiej, która spod ,jarzma fanariockiego“ popadnie w jeszcze gorsze - ,jarzmo jezuickie“39. Katolicy, określani najczęściej przez Rakowskiego „,jezuitami“ lub „papistami“, reprezentowali nie tylko wrogie interesy ekspansywnego katolicyzmu, ale i obcą kulturę, która miała prowadzić do wynarodowienia Bułgarów ${ }^{40}$.

Zarówno Cankow, jak i Rakowski, byli świadomi, że rozwiązanie kwestii cerkiewnej nie zależała wyłącznie od Bułgarów, patriarchatu Konstantynopola, Kościoła katolickiego oraz Imperium Osmańskiego, ale i od głównych decydentów ówczesnej sceny europejskiej - koncertu mocarstw ${ }^{41}$. W polemikach prowadzonych na łamach „Bułgarii“ i „Dunajskiego Łabędzia“ stale powracano do problematyki współpracy w skali międzynarodowej. Zwolennicy unii opowiadali się za związaniem Bułgarów z Francją, uchodzącą $\mathrm{w}$ tym czasie za protektora katolicyzmu w świecie ${ }^{42}$. Niewątpliwie wpływ na ten pogląd miał fakt, że „Bułgaria“ była drukowana w podziemiach francuskiego klasztoru San Benedetto przy wsparciu finansowym lazarystów, a także rządu w Paryżu ${ }^{43}$. Równocześnie ruch unicki sprzeciwiał się stanowczo współpracy z dworem w Petersburgu, co było niewątpliwie odzwierciedleniem nastrojów rozczarowania Rosją, jakie panowały wśród ludności bułgarskiej po wojnie krymskiej ${ }^{44}$, ale i efektem związków z Polakami z Hôtelu Lambert ${ }^{45}$. „Bułgaria“ oskarżała Rosjan o wspieranie patriarchatu Konstantynopola oraz działania wymierzone w ruch cerkiewny. Krytykowano udział Bułgarów w wojnach rosyjsko-tureckich, podkreślając, że w trakcie rokowań pokojowych dyplomacja carska konsekwentnie ignorowała sprawę bułgarską. Według Cankowa, rząd w Petersburgu

Joannisa Kapodistriasa, pierwszego prezydenta niepodległej Grecji (1827-1831), który nazywał wyższe duchowieństwo oraz fanariotów „,chrześcijańskimi Turkami” oraz „pomiotami szatana”. Zob. „Дунавски лебед“, r. 1, nr 4, 6.10.1860, s. 1; R. Clogg, Historia Grecji nowożytnej, Książka i Wiedza, Warszawa, 2006, s. 59; T. Czekalski, Kościót prawosławny w życiu politycznym nowożytnego państwa greckiego, w: Religijna mozaika Bałkanów, red. M. Walczak-Mikołajczakowa, Collegium Europaeum Gnesnense, Gniezno, 2008, s. 145.

39 „Дунавски лебед“, r. 1, nr 7, 27.10.1860, s. 3; „Дунавски лебед“, r. 1, nr 11, 22.11.1860, s. 3.

40 „Дунавски лебед“, r. 1, nr 10, 15.11.1860, s. 1-2.

${ }^{41}$ Г. Минчев, op. cit., s. 159.

42 „България“, r. 1, nr 16, 11.07.1859, s. 3; Od początków rządów Ludwika Napoleona Bonaparte, jeszcze w okresie prezydentury (1848-1851), jego związki z Kościołem katolickim były niezwykle wyraźne. Wielokrotnie dawał temu wyraz w prowadzonej przez siebie polityce zagranicznej. W 1849 roku wojska francuskie restaurowały Państwo Kościelne, w którym stacjonowały aż do 1871 roku, chroniąc posiadłości papiestwa przed rozwijającym się Risorgimento. Działalność francuskich misji katolickich była związana z polityką kolonialną III Cesarstwa, prowadzoną w Indochinach i Afryce Północnej. Podobnie były one wykorzystywane przez Francję w rywalizacji o wpływy na obszarze Półwyspu Bałkańskiego. Zob. Sprawa butgarska, cz. 2, Grodzisk 1862, s. 10; R. Price, Napoleon III and the Second Empire, Taylor \& Francis, New York, 1997, s. 16.

43 „България“, r. 1, nr 23, 29.08.1859, s. 1; С. Чилингиров, op. cit., s. 174; P. Stafford, Eugène Boré and the Bulgarian Catholic Movement, „Vincentian Heritage Journal“, 16, 1996, 2, s. 201-202.

${ }^{44}$ К. Иречек, op. cit., s. 578-581.

45 Dzięki agentom Hôtelu Lambert Cankow nawiązał współpracę z lazarystami i otworzył drukarnię w San Benedetto. Potem Czartoryski wspierał finansowo „Bułgarię” - w kwietniu 1860 roku przekazał 20 tys. piastrów na rzecz jej redakcji. Zob. L. Widerszal, op. cit., s. 119. 
wykorzystywał Bułgarów do realizacji swoich imperialnych interesów na Bałkanach, przedmiotowo posługiwał się hasłami słowianofilskimi oraz podtrzymywał sztuczną jedność prawosławia w regionie, opartą na dominacji Greków w strukturach kościelnych ${ }^{46}$. Redaktor „Bułgarii” podkreślał także szkodliwy wpływ kultury rosyjskiej na bułgarską, który miał prowadzić do zacofania i rusyfikacji. Obrazował to przez pełen zapożyczeń język jego konkurentów (tu wskazywał na publicystów „Gazety Carogrodzkiej“) $)^{47}$. Inny pogląd reprezentował w tej kwestii „Dunajski Łabędź“. Początkowo, podobnie jak finansowana przez rząd rosyjski „Gazeta Carogrodzka“, stał na stanowisku rusofilskim. Jednak wobec wielu rozczarowań związanych ze wspieraniem patriarchatu Konstantynopola przez Rosję, Rakowski ostudził swój entuzjazm związany z współpracą rosyjsko-bułgarską. Z drugiej strony na łamach „Dunajskiego Łabędzia" nigdy otwarcie nie krytykował Petersburga, a często powoływał się na idee jedności słowiańskiej, tradycję współpracy z Rosjanami oraz zbieżne interesy obu narodów ${ }^{48}$. „Dunajski Łabędź“ przyjmował natomiast zdecydowane stanowisko wobec świata zachodniego z Francją na czele. Zarzucał mocarstwom zachodnioeuropejskim, że patrzą z wyższością na Bułgarów, jak na „dzikusów“, „Tatarów“, „barbarzyńców“, których należy „ucywilizować”, czyli zasymilować przez narzucenie im religii katolickiej ${ }^{49}$. „Dunajski Łabędź“ ostrzegał, że Francja wspierając ruch unicki realizuje swoją politykę imperialną, a nawet dąży do stworzenia z Bułgarii nowej kolonii ${ }^{50}$.

Argumentacja stron sporu często odwoływała się do tradycji średniowiecznej można nawet powiedzieć, że Cankow i zwolennicy unii stworzyli odrębną wersję dziejów Bułgarii sprzed podboju tureckiego, pełną nadinterpretacji oraz przekłamań, przy pomocy której starali się udowodnić historyczne związki Bułgarów z katolicyzmem ${ }^{51}$. Według periodyku, po przyjęciu chrześcijaństwa w 861 roku miało

46 „България“, r. 1, nr 1, 25.03.1859, s. 2; „България“, r. 1, nr 3, 11.04.1859, s. 4; „България“, r. 1, nr $12,13.06 .1859$, s. $1-2$.

${ }^{47}$ Cankow podawał w tym przypadku przykłady najbardziej powszechnych słów, m.in. „Gazeta Carogrodzka“ zamiast bułgarskiego czasownika видя, oznaczającego „widzieć, patrzeć”, używała rusyсуzmu смотря. Zob. „България“, r. 1, nr 17, 18.07.1859, s. 2; Co ciekawe, po powstaniu państwa bułgarskiego w 1878 roku Cankow stał się jednym z najbardziej zagorzałych rusofili na bułgarskiej scenie politycznej oraz konsekwentnym obrońcą protektoratu rosyjskiego w Bułgarii. Zob. Програми, програмни документи и устави на бържоазните партии в България 1879-1918, ред. В. Николова, Д. Саздов, Наука и изкуство, София, 1992, s. 365-371; J. Grzegorzewski, Rok przewrotów. Bułgarya 1885-1886, Lwów, 1900, s. 109-111.

48 „Дунавски лебед“, r. 1, nr 13, 6.12.1860, s. 1; W późniejszym okresie poglądy Rakowskiego były coraz bardziej antyrosyjskie i z czasem upodobniły się do punktu widzenia prezentowanego przez Cankowa na łamach „Bułgarii”. Dobrym tego przykładem jest broszura wydawana po zamknięciu „Dunajskiego Łabędzie" zob. Г. С. Раковски, Преселение в Русия или руската убийствена политика за българите, София, 1861.

49 „Дунавски лебед“, r. 1, nr 23, 28.02.1861, s. 1-2. Więcej o stereotypach funkcjonujących w społeczeństwie zachodnim na temat Półwyspu Bałkańskiego zob. B. Jezernik, Dzika Europa. Bałkany w oczach zachodnich podróżników, Universitas, Kraków, 2007; M. Todorova, Bałkany wyobrażone, Wydawnictwo Czarne, Wołowiec, 2008.

50 „Дунавски лебед“, r. 1, nr 12, 29.11.1860, s. 1.

${ }^{51}$ Zob. T. Wasilewski, Historia Bułgarii, Ossolineum, Wrocław, 1970, s. 51-122; Kontakty Bułgarów z Kościołem katolickim w średniowieczu miały faktycznie znacznie bardziej ograniczony zasięg 
dojść do konfliktu bułgarsko-greckiego o język liturgii, który wynikał z próby narzucenia Słowianom greki przez patriarchat w Konstantynopolu. Skutkiem tego miało być zwrócenie się bułgarskiego księcia Borysa I (852-889) do Rzymu z prośbą o przysłanie legatów, którzy pomogliby zorganizować niezależną od Greków hierarchię. Papież Mikołaj I (858-867) miał wysłuchać prośby monarchy i oddelegować nad Dunaj dwóch biskupów. Tak więc, według Cankowa, to Kościół rzymski, a nie bizantyjski, położył fundamenty chrześcijaństwa w Bułgarii i ustanowił pierwszą bułgarską hierarchię kościelną. Jednak po śmierci Mikołaja I oraz zakończeniu schizmy Focjusza (861-867) ${ }^{52}$, Pliska miała stać się ponownie obszarem wpływów greckich. Rzym kolejny raz miał przyczynić się do wyzwolenia Bułgarii spod wpływów duchowieństwa bizantyjskiego za pośrednictwem św. św. Konstantyna-Cyryla i Metodego. Cankow uwydatniał fakt, że papiestwo nie tylko wspierało misję morawską i ściśle współpracowało z braćmi sołuńskimi, ale także przyczyniło się do kodyfikacji języka staro-cerkiewno-słowiańskiego oraz wprowadzenia go do liturgii. Za sprawą uczniów Cyryla i Metodego, którzy przybyli do Bułgarii w 886 roku po śmierci św. Metodego, miało dojść do odnowienia więzi Bułgarów z Kościołem rzymskim. Według Cankowa, w okresie największej potęgi pierwszego carstwa bułgarskiego za rządów Symeona I Wielkiego (893-927) Bułgarzy mieli współpracować z Rzymem, m.in. tytuł cara Bułgarów i samowładcy Greków monarcha miał otrzymać od papieża Jana X (914-928). Ponowne związanie Cerkwi bułgarskiej z patriarchatem Konstantynopola za panowania Piotra I (927-969) miało doprowadzić do upadku pierwszego carstwa w 1018 roku. Według „Bułgarii“, odrodzenie państwowości bułgarskiej pod koniec XII wieku było związane z odnowieniem unii z Rzymem przez Kałojana (1197-1207). Jednak nie był to stan długotrwały - w wyniku konfliktu króla Bułgarii z krzyżowcami i bitwy pod Adrianopolem w 1205 roku stosunki ze Stolicą Apostolską uległy ochłodzeniu. Unia z Rzymem miała utrzymać się aż do 1237 roku, kiedy Iwan Asen II (1218-1241), pretendując do roli następcy cesarzy bizantyjskich, miał przyjąć ponownie prawosławie. Według Cankowa, w wyniku powrotu do „religii schizmatyckiej“, grzechów dynastii bułgarskich oraz szerzącego się manicheizmu bogomilskiego pod koniec XIV wieku, Bułgarię spotkała kara boska pod postacią najazdów tureckich sprowadzonych do Europy przez naiwność i głupotę bizantyjskich Paleologów ${ }^{53}$.

zob. W. Stępniak-Minczewa, I francescani in Bulgaria. Blasius Kleiner: un francescano in viaggio per i Balcani (sulla base della «Storia della Bulgaria» din Blasius Kleiner), w: I francescani nella storia dei popoli balcanici, ed. V. Nosilia, M. Scarpa, Centro interdipartimentale di studi balcanici e internazionali, Genua 2011, s. 59-68.

52 Zob. H. Chadwick, Historia rozłamu Kościoła Wschodniego i Zachodniego, Wydawnictwo WAM, Kraków, 2009, s. 199-203.

53 „България“, r. 1, nr 17, 18.07.1859, s. 1; „България“, r. 1, nr 29, 10.10.1859, s. 2-3; „България“, r. 1, nr 31, 24.10.1859, s. 2; „България“, r. 1, nr 30, 17.10.1859, s. 2-3; „България“, r. 1, nr 34, 14.11.1859, s. 2; W podobny sposób dzieje średniowiecznej Bułgarii były przedstawiane w drukach ulotnych misjonarzy katolickich zob. H. Kajsiewicz, O unii butgarskiej. Rys historyczny, Paryż, 1863, s. 7-34; N. Cybart, Nieznana historia Butgarii pióra krakowskiego jezuity Józefa Hołubowicza, w: Nowe spojrzenie na kul- 
Zwolennicy grekokatolicyzmu (podobnie jak misjonarze katoliccy) starali się przy pomocy własnej wersji historii średniowiecznej Bułgarii zbudować wrażenie, że unia nie jest obca kulturze bułgarskiej, a oznacza powrót narodu do prawdziwych korzeni chrześcijaństwa. Ruch unicki za swoich patronów uznał św. Konstantyna (Cyryla) i Metodego, którzy byli traktowani jako symbol grekokatolicyzmu - trzeciej drogi chrześcijaństwa pod patronatem Kościoła katolickiego ${ }^{54}$. Cankow podkreślał, że Bułgarzy nie muszą uznawać autorytetów greckich Ojców Kościoła, skoro mają własnych, reprezentowanych przez „Apostołów Słowian” 55 .

Argumentacja historyczna „Dunajskiego Łabędzia“ bazowała na dziejach arcybiskupstwa ochrydzkiego ${ }^{56}$ oraz autokefalii bułgarskiej, której początki sięgają 927 roku. Rakowski w ten sposób chciał udowodnić, że prawa Bułgarów do niezależnych instytucji cerkiewnych nigdy nie wygasły, a są nielegalnie łamane przez Greków ${ }^{57}$. Od pierwszych numerów czasopismo publikowano obszerne artykuły dotyczące historii bułgarskiej Cerkwi prawosławnej, począwszy od przyjęcia chrześcijaństwa aż do czasów współczesnych autorowi ${ }^{58}$. Miały one stanowić potwierdzenie formułowanych przez Rakowskiego argumentów o bezprawnym zwierzchnictwie patriarchatu Konstantynopola nad Bułgarami ${ }^{59}$. Podobnie jak Cankow, redaktor „Dunajskiego Łabędzia“ dopuszczał się przekłamań (choć nie tak daleko idących) na potrzeby prowadzonej przez siebie propagandy, m.in. twierdził, że arcybiskupstwo Ochrydu zachowało swój bułgarski charakter aż do likwidacji w 1767 roku $^{60}$.

Dyskusja między „Dunajskim Łabędziem“ a „Bułgarią“ wchodziła także w zakres sporów dogmatycznych, które sięgały swoimi początkami średniowiecznych polemik między Rzymem a Konstantynopolem o kwestie: filioque, używania przaśnego chleba w eucharystii, istnienia czyśćca, celibatu wśród księży, noszenia zarostu

turę bułgarska, red. D. Ivanowa, T. Lewaszkiewicz, N. Reczek, Katedra Filologii Słowiańskiej UAM, Poznań, 2008, s. 25-28.

54 „България“, r. 1, nr 9, 23.05.1859, s. 1-3; „България“, r. 1, nr 11, 6.06.1859, s. 3; „България“, r. 1, nr 40, 24.12.1859, s. 1; W. Jóźwiak, Święci Cyryl i Metody w koncepcji unitów bułgarskich, w: Święci w kulturze i duchowości dawnej i wspótczesnej Europy, red. W. Stępniak-Minczewa, Z. Kijas, PAT, Kraków 1999, s. 145-154.

55 „България“, r. 1, nr 9, 23.05.1859, s. 2.

${ }^{56}$ Więcej o historii arcybiskupstwa Ochrydu zob. И. Снегаров, История на Охридската Архиепископия, т. 1: От основаването ѝ до завладяването на Балканския полуостров от туриите, „М. Дринов“, София, 1995; Idem, История на Охридската Архиепископия, т. 2: От падането под туриите до нейното унищожение, „М. Дринов“, София, 1995.

57 „Дунавски лебед“, r. 1, nr 7, 27.10.1860, s. 1; „Дунавски лебед“, r. 1, nr 18, 24.01.1861, s. 1-2.

58 „Дунавски лебед“", r. 1, nr 1, 1.09.1860, s. 3-4; „Дунавски лебед“, r. 1, nr 2, 22.09.1860, s. 4; „Дунавски лебед“, r. 1, nr 3, 29.09.1860, s. 3-4; „Дунавски лебед“, r. 1, nr 4, 6.10.1860, s. 4; „Дунавски лебед“, r. 1, nr 5, 18.10.1860, s. 4; „Дунавски лебед“, r. 1, nr 7, 27.10.1860, s. 6; „Дунавски лебед“, r. 1, nr 8, 1.11.1860, s. 4 .

${ }^{59}$ L. Widerszal, op. cit., s. 96-97; Г. Минчев, op. cit., s. 158-159.

${ }^{60}$ Faktycznie od XVI wieku autokefalia ulegała systematycznej hellenizacji - najwyższe stanowiska kościelne były zdominowane przez Greków, a cerkiewno-słowiański był stopniowo wypierany z liturgii i szkół przez grekę. Ostatnim bastionem piśmiennictwa słowiańskiego pozostawały w Bułgarii monastyry. Zob. И. Снегаров, История на Охридската..., т. 2, s. 37 et passim; Н. Генчев, Българската култура $X V$-XIX в., УИ „Климент Охридски”, София, 1988, s. 115-118. 
przez duchowieństwo oraz nadrzędnej pozycji papieża w świecie chrześcijańskim ${ }^{61}$. $\mathrm{Na}$ łamach czasopism wielokrotnie powracano do spraw włączenia przez katolików wzmianki o Synu (łac. filioque) do credo. Rakowski odwoływał się do argumentacji Cerkwi prawosławnej, pisząc, że nie można dodawać żadnych nowych elementów do wyznania wiary zatwierdzonego w wersji kanonicznej przez sobory (dokładnie przez sobór konstantynopolitański I w 381 roku), a taką zmianę należy traktować jako przejaw herezji. W ten sposób starano się udowodnić, że Zachód - według świata prawosławnego i periodyku „Dunajski Łabędź“ - błędnie rozumiał istotę jedności Trójcy Świętej, czyli jednego z najważniejszych dogmatów chrześcijaństwa ${ }^{62}$. Tymczasem Cankow, odwołując się do nauk Kościoła katolickiego, dowodził, że likwidacja filioque z credo była efektem wpływu arianizmu (zaprzeczającego istnienia Trójcy Świętej oraz uznającego pochodzenia Syna od Boga Ojca) na prawosławie, które w ten sposób stało się herezją, porównywalną do nauk Ariusza ${ }^{63}$. W podobnym duchu prowadzono dyskusję na temat czyśćca (prawosławni postrzegali go jako symboliczną drabinę prowadzącą do nieba, natomiast katolicy jako określone miejsce), a także kwestii celibatu (dla Rakowskiego był on nie tylko niekanoniczny, ale i sprzeczny z tradycją i dobrymi obyczajami) ${ }^{64}$. Redaktor „Dunajskiego Łabędzia“" wykorzystywał także fakt braku obowiązku noszenia bród przez duchownych katolickich - wizerunek księży „o zgolonych wąsach, chudych, żółtych niczym śmierć“65 powiązywał ze stereotypem wiecznie knujących jezuitów, których celem jest unicestwienie Cerkwi prawosławnej oraz przejęcie kontroli nad światem ${ }^{66}$.

Najistotniejszy spór dogmatyczny między omawianymi gazetami dotyczył kwestii prymatu papieża nad wspólnotą chrześcijańską. Według świata prawosławnego - a także odwołującego się do tej argumentacji Rakowskiego - głową Kościoła jest Chrystus, który jako jedyny posiada władzę nad wszystkimi chrześcijanami. Podkreślano, że św. Piotr był jedynie biskupem Rzymu, a nie zwierzchnikiem całej wspólnoty. Na łamach „Dunajskiego Łabędzia“ starano się wykazać błędne interpretacje tych części Biblii, które dla katolików świadczyły o pierwszeństwie metropolity rzymskiego, m.in. na niewłaściwe przetłumaczenia słowa „skała” we fragmencie „Ty jesteś Piotr [czyli Skała], i na tej Skale zbuduję Kościół mój” (Mt 16, 18) ${ }^{67}$.

${ }^{61}$ Zob. A. Naumow, Ksenofobia i nieufność jako mechanizmy wspólżycia chrześcijan, w: Chrześcijański Wschód i Zachód..., s. 87-97.

62 „Дунавски лебед“, r. 1, nr 22, 21.02.1861, s. 3; „Дунавски лебед“, r. 1, nr 24, 7.03.1861, s. 4; Г. С. Раковски, Отговор Чокърляну. Доказаящ че Въсточная иърква е истинно православна,, ред. Г. Минчев, w: Wielkie mity narodowe..., s. 134-137; H. Chadwick, op. cit., s. 199-201.

63 „България“", r. 1, nr 36, 28.11.1859, s. 1-2; H. Chadwick, op. cit., s. 45-52.

64 „Дунавски лебед“, r. 1, nr 23, 28.02.1861, s. 3.

65 „Дунавски лебед“, r. 1, nr 13, 6.12.1860, s. 2.

${ }^{66}$ G. Minczew, op. cit., s. 115-116.

${ }^{67}$ Trzeba zaznaczyć, że analizy językoznawcze Rakowskiego często ocierały się o absurd. Chociażby w swojej rozprawie Klucz do języka bułgarskiego (Ключ болгарскаго язика, 1858) starał się wykazać, że bułgarski jest bezpośrednią kontynuacją sanskrytu. Udowadniał to poprzez porównanie leksemu „byćc w obu językach. Tego typu związki można dostrzec we wszystkich językach indoeuropejskich, a nie wyłącznie w bułgarszczyźnie. Zob. G. S. Rakowski, Przedmowa do „Klucza do języka butgarskiego”, 
Podkreślano, że św. Piotr trzykrotnie wyparł się swojego nauczyciela, a także powoływano się na zasadę równości między wszystkimi Apostołami. Rakowski formułował zarzut, że katolicy niesłusznie starają się stawiać biskupa Rzymu na równi z Synem Bożym ${ }^{68}$. Tymczasem Cankow uznawał papieża za niekwestionowaną głowę całego świata chrześcijańskiego, co wynikało z tytułu następcy twórcy instytucji Kościoła ${ }^{69}$. Równocześnie twierdził, że patriarchat Konstantynopola jest jedynie diecezją, która formalnie powinna podlegać Ojcowi Świętemu ${ }^{70}$. Wyrażało się to w języku Cankowa, który konsekwentnie nazywał patriarchę Cyryla VII „,biskupem carogrodzkim“"71, a nawet „panem Cyrylem“"72.

Wszystkie te zabiegi retoryczne oraz odwoływanie się do sporów dogmatycznych między zachodnimi a wschodnimi chrześcijanami miało prowadzić do udowodnienia, że - podążając za tokiem rozumowania „Bułgarii““ - prawosławie jest faktycznie herezją, odstępstwem od prawdziwej wiary reprezentowanej przez autorytet Ojca Świętego, natomiast - w przypadku „Dunajskiego Łabędzia“ - że ortodoksja jest jedyną słuszną drogą chrześcijaństwa, której zaprzeczeniem jest katolicyzm, ignorujący postanowienia soborów powszechnych. Czytelnik otrzymywał od redaktorów jasne sygnały - wybór złej drogi będzie równoznaczny z odebraniem sobie szansy na zbawienie $^{73}$. Mimo że polemik dogmatycznych toczonych na łamach omawianych periodyków nie można uznać za zjawisko oryginalne, a autorzy bazowali na argumentacji, stosowanej właściwie już od IV wieku ${ }^{74}$, to były one niezwykle ważnym elementem dyskusji toczonych na przełomie lat pięćdziesiątych i sześćdziesiątych wśród Bułgarów, definiującym ich stosunek do własnej tradycji oraz Zachodu. Publicyści odwoływali się do niezwykle istotnej sfery życia ówczesnej ludności bułgarskiej - religijności, która stanowiła jeden z kluczowych paradygmatów tożsamości mieszkańców Imperium Osmańskiego w tym okresie ${ }^{75}$.

w: Naród i kultura. Antologia esejów i artykułów o narodzie i kulturze butgarskiej, red. W. Gałąza, UJ, Kraków, 1985, s. 19-25; L. Widerszal, op. cit., s. 97-98.

68 „Дунавски лебед“, r. 1, nr 3, 29.09.1860, s. 3; „Дунавски лебед“, r. 1, nr 26, 21.03.1861, s. 4; Г. С. Раковски, Отговор Чокърляну..., s. 137-138; W świecie prawosławnym św. Piotr często był utożsamiany wręcz ze zdrajcą, co jest widoczne chociażby w ukraińskim folklorze zob. M. Zowczak, Biblia ludowa. Interpretacje wątków biblijnych w kulturze ludowej, Wydawnictwo UMK, Toruń, 2013, s. 347-353.

69 „България“, r. 1, nr 17, 18.07.1859, s. 1.

70 „България“", r. 1, nr 19, 1.08.1859, s. 2.

71 „България““, r. 1, nr 21, 14.08.1859, s. 2.

72 „България“", r. 1, nr 8, 16.05.1859, s. 2-3.

73 „Дунавски лебед“, r. 1, nr 23, 28.02.1861, s. 3-4.

74 Argumenty formułowane przez Rakowskiego odwoływały się do listu okólnego patriarchów Konstantynopola, Aleksandrii, Antiochii i Jerozolimy z 1848 roku, będącego reakcją na encyklikę papieża Piusa IX In suprema Petri. Zob. Окружное послане Единой, Святой, Соборной и Апостольской Церкви ко всем православным християнам (перевод с греческого), [w:] Догматические послания православных иерархов XVII-XIX веков о православной вере, Свято-Тройская Сергиева Лавр, 1995, s. 198-244; A. Naumow, op. cit., s. 87.

${ }^{75}$ N. Clayer, The Dimension of Confessionalisation in the Ottoman Balkans at the Time of Nationalisms, w: Conflicting Loyalties in the Balkans. The Great Powers, the Ottoman Empire, and Nation- 
Przyjęcie unii (za czym opowiadała się „Bułgaria”) bądź utrwalenie wiary ortodoksyjnej (w myśl programu nurtu narodowego stronnictwa cerkiewnego, popieranego przez Rakowskiego) niosłyby ze sobą istotne konsekwencje dla kształtu kultury bułgarskiej. Dla redaktora „Dunajskiego Łabędzia“" prawosławie było nie tylko nieodłącznym elementem dziedzictwa Bułgarów, ale wręcz wyznacznikiem bułgarskości przyjęcie katolicyzmu było równoznaczne z wyrzeczeniem się bycia częścią narodu ${ }^{76}$. Według Rakowskiego, okcydentalizacja, proponowana przez ruch unicki, prowadziłaby do rozbicia jedności narodowej, w wyniku której „największy naród zamieszkujący Półwysep Bałkański“"zostałby podzielony na sztuczne wspólnoty „Bułgaro-katolików“, „Bułgaro-protestantów“ oraz „Bułgaro-moskali“, a następnie zniknęłaby, tracąc swoją odrębność pod wpływem obcych modeli kulturowych ${ }^{77}$. Rakowski wyśmiewał zafascynowanie europejskimi zwyczajami wśród zwolenników obozu Cankowa, odwołując się do obrazów popularnych wówczas w literaturze bułgarskiej, np. w twórczości Dobri Wojnikowa $^{78}$, Lubena Karawełowa ${ }^{79}$, Wasiła Drumewa ${ }^{80}$ czy Petko Raczowa Sławejkowa ${ }^{81}$. Podobnie jak czarne charaktery w najważniejszej komedii Wojnikowa Błędnie zrozumiana cywilizacja (Криворазбраната цивилизация, 1871), zwolennicy unii byli przedstawiani przez Rakowskiego jako zniewieściali dandysi - pozbawieni bród, palący damskie papierosy, przeplatający w bułgarszczyźnie słowa z języka francuskiego, którego nawet dobrze nie znali ${ }^{82}$. Wobec tych zarzutów zaskakuje fakt, że to „Dunajski Łabędź“, a nie „Bułgaria“, była drukowana w połowie w języku francuskim (od numeru 16. z dnia 7 stycznia 1860 roku) ${ }^{83}$. Tymczasem, według Cankowa, przyjęcie grekokatolicyzmu miało otworzyć Bułgarów na spuściznę kultury europejskiej, od której zostali odcięci na początku panowania tureckiego na Półwyspie Bałkańskim.

Building, ed. H. Grandits, N. Clayer, R. Pichler, I.B. Tauris, London, 2011, s. $89-91$ et passim; F. M. Göçek, Ethnic Segmentation, Western Education, and Political Outcomes: Nineteenth-Century Ottoman Society, „Poetics Today”, 14, 1993, 3, s. 507-538.

76 „Дунавски лебед“, r. 1, nr 11, 22.11.1860, s. 3; Nie była to opinia odosobniona, co obrazuje sytuacja z 1879 roku, kiedy urzędnicy nowopowstałego państwa bułgarskiego zarzucali unitom z miejscowości Topuzłare (obecnie: Zornica) oraz Sazłykioj (obecnie: Trystikowo), że z racji wyznawanej przez nich religii nie są Bułgarami. Zob. Sprawozdanie Missyi Butgarsko-katolickiej O.O. Zmartwychwstańców w Adrianopolu za rok szkolny 1878/1879, Adrianopol, 12.12.1879, Biblioteka xx. Czartoryskich, rkps nr 6748 III.

77 „Дунавски лебед“, r. 1, nr 15, 20.12.1860, s. 1; „Дунавски лебед“, r. 1, nr 16, 7.01.1861, s. 2; С. Елдъров, Католичите в България (1878-1989). Историческо изследване, Международен центьр за изследване на малцинствата и културните взаимодействия в България, София, 2002, s. 64.

78 Д. Войников, Криворазбраната цивилизация, [w:] Българска възрожденска драма, ред. Д. Леков, Библиотека за ученика, София, 1973, s. 17-100.

79 Л. Каравелов, Прогресист, [w:] Idem, Съчинения, т. 7, Русе, 1887, s. 122-158.

${ }^{80}$ В. Друмев, Ученик и благодатели или чуждото си е все чуждо, [w:] Idem, Нещастна фамилия. Ученик и благодател, Български писател, София, 1989, s. 119-266.

${ }^{81}$ Przykładem tego jest komedia Krynolina (Малакова, 1864), którą P. R. Sławejkow opublikował na łamach wydawanego przez siebie czasopisma „Kobza” („Гайда”). Zob. „Гайда”, г. 1, nr 22, 1864, s, 4-7; „Гайда”, г. 1, nr 23, 1864, s. 7-8; „Гайда”, г. 1, nr 24, 1864, s. 7-8.

82 „Дунавски лебед“, r. 1, nr 11, 22.11.1860, s. 2-3.

$83 \mathrm{~W}$ ten sposób Rakowski chciał dotrzeć do jak najszerszego grona odbiorców. A. Nowosad, op. cit., s. 101. 
Ruch unicki widział w okcydentalizacji możliwość realnego rozwoju bułgarskiej literatury, szkolnictwa oraz nauki ${ }^{84}$, a także szansę na poprawę poziomu życia w Bułgarii, dzięki wszystkim osiągnięciom cywilizacyjnym Zachodu ${ }^{85}$. Na łamach „Bułgarii““ podkreślano, że naród nie będzie się rozwijał pod wpływem kontaktów z Rosjanami czy Grekami (,w takim samym stopniu zacofanymi, co Bułgarzy”), należy natomiast wzorować się na tych, którzy wodzą kulturalny prym w świecie, czyli na Francuzach ${ }^{86}$. Warto zwrócić uwagę, że był to dopiero początek dyskusji o kwestii stosunku kultury bułgarskiej do cywilizacji europejskiej. Pozbawiony wątku religijnego, był on kontynuowany w wolnej Bułgarii. Dyskusje na tym polu nasiliły się w szczególności od lat dziewięćdziesiątych XIX wieku, co było związane z rozwojem modernizmu w literaturze bułgarskiej oraz sporem między tradycjonalistami z Iwanem Wazowem na czele a „młodymi“, reprezentowanymi przez tzw. Czwórkę „Myśli““ (Penczo Sławejkow, Petko Todorow, Pejo Jaworow, dr Krystio Krystew $)^{87}$.

W przepełnionych emocjami dyskusjach prowadzonych między omawianymi czasopismami nie zabrakło ataków o charakterze osobistym, celem których było ośmieszenie oraz oczernienie oponentów. Argumentacja stosowana w tekstach publicystycznych przez Cankowa oraz Rakowskiego często nie miała charakteru racjonalnego, opartego na logice czy rozumnej ocenie wydarzeń, a odwoływała się do sfery uczuć, emocji oraz poczucia dumy z bycia Bułgarem. Była to cecha charakterystyczna całej publicystyki okresu odrodzenia narodowego ${ }^{88}$. Autorzy odwoływali się do stereotypów wytworzonych przez bułgarską kulturę odrodzenia narodowego, które przedstawiały Greka jako podstępnego, otyłego rozpustnika, skupionego wyłącznie na pomnażaniu swojego majątku ${ }^{89}$. Dla Rakowskiego działacze uniccy byli zdrajcami narodu, a nawet ,jezuickimi kurwami“, „derwiszami z San Benedetto“, „papieskimi łapownikami“"90 - bandą nieudaczników, którzy po tym jak nie powiodła im się kariera we Francji, wracali do Bułgarii, by sprzedać własną ojczyznę i w ten sposób dorobić się majątku ${ }^{91}$. Cankow również nie oszczędzał swoich przeciwników - posługiwał się podobnymi zarzutami, oskarżając inne stronnictwa ruchu o wy-

84 „България“, r. 1, nr 3, 11.04.1859, s. 1.

85 „България“", r. 1, nr 6, 1.05.1859, s. 1.

86 „България“, r. 1, nr 17, 18.07.1859, s. 2.

87 Więcej na temat sporu modernistów z tradycjonalistami zob. С. Игов, История на българската литература, Циела, София, 2002, s. 435-495; Б. Ангелов, Дебатът Славейков - Вазов, или идеологът на „Мисъл” срещу идеолога на нацията, Литературен клуб, Шумен, 1996.

${ }^{88}$ B. Rusin, Kryzys Imperium Osmańskiego w świetle bułgarskiej publicystyki odrodzeniowej (przypadek Christo Botewa, Lubena Karawełowa i Georgiego Rakowskiego), „Studenckie Zeszyty Naukowe Instytutu Filologii Słowiańskiej UJ", 3, 2013, 1, s. 90.

${ }^{89}$ Stereotypowe przedstawienie Greka po raz pierwszy pojawiło się w dialogu Płacz biednej Matki Butgarii (Плач бедния мати Болгарии, 1846) Neofita Bozwelego. Zob. Н. Бозвели, Мати Болгария, w: Възрожденски страници. Антология, т. 1, ред. П. Динеков, Български писател, София, 1969, s. $107-$ 119. Szerzej o rozwoju stereotypu Greka w kulturze bułgarskiej w tym okresie zob. Н. Данова, Образи на гъричи и западноевропейци в българската книжнина през XVIII-XIX век, „Либерален преглед”, 2014, 3, s. 888-922.

90 G. Minczew. op. cit., s. 105, 119.

91 „Дунавски лебед“, r. 1, nr 20, 7.02.1861, s. 6. 
sługiwanie się Grekom, co wyrażał poprzez grecyzację imion działaczy cerkiewnych: w jego artykułach Aleksandyr Ekzarch jest Ekzarchosem, natomiast Gawrił Krystewicz - Christodisem. Redaktor „Bułgarii” dowodził, że jego oponenci sami chcą zostać „papieżami Bułgarów“ i zając stanowiska hierarchów konstantynopolitańskich. „Gazeta Carogrodzka“ została przez Cankowa natomiast przemianowana na „Fanar“ („Фанария“") ${ }^{92}$. Podobnie jak Rakowski, redaktor „Bułgarii“" nie stronił też od wulgaryzmów, nazywając swoich przeciwników m.in. „świńskimi gadzinami“933. Jak widzimy, imperatywy, którymi posługują się obie strony sporu, miały podobny charakter - oskarżeń o zdradę interesów narodowych na rzecz zdemonizowanych jezuitów bądź wyzyskujących Bułgarów Greków.

Polemiki toczone między „Bułgarią” oraz „Dunajskim Łabędziem” stanowiły odzwierciedlenie głównych dylematów, przed jakimi stanął bułgarski ruch cerkiewny na przełomie lat pięćdziesiątych oraz sześćdziesiątych XIX wieku. Impas w negocjacjach bułgarsko-greckich doprowadził w 1860 roku do dwóch przełomowych wydarzeń: schizmy wielkanocnej Iłariona Makariopolskiego (którą poparł Rakowski) oraz przyjęcia unii kościelnej przez Bułgarów (czego inicjatorem był Cankow). Artykuły publikowane na łamach przedstawionych periodyków stanowią dowód na to, że ruch cerkiewny wykraczał poza problematykę religijną i miał przede wszystkim charakter polityczny. Dyskusje wokół unii kościelnej i dogmatów chrześcijaństwa stanowiły punkt wyjścia do rozważań nad najważniejszymi zagadnieniami związanymi z realizacją celów bułgarskiego ruchu narodowego (czyli uzyskaniem autonomii w ramach państwa Osmanów), a także z rozwojem kultury bułgarskiej (przyjęcie unii miało nieść ze sobą okcydentalizację, natomiast utrwalenie związków z prawosławiem - wzmocnienie sojuszu z Rosjanami). Wprawdzie Rakowski i Cankow cały czas podkreślali znaczenie religii w życiu Bułgarów, jednak często ujawniało się u nich przedmiotowe traktowanie instytucji kościelnych $w$ realizacji celów politycznych, co należy uznać za jedną z najważniejszych cech całego ruchu cerkiewnego. Konflikt bułgarsko-grecki oraz dyskusje prowadzone na łamach „Bułgarii” i „Dunajskiego Łabędzia” obrazują także specyficzne warunki, w jakich rozwijał się bułgarski ruch narodowy w państwie osmańskim sfera publiczna była nierozerwalnie związana z instytucjami religijnymi, które stanowiły podstawowe narzędzie do realizacji celów politycznych poszczególnych wspólnot etnicznych.

\section{BIBLIOGRAFIA:}

Chadwick Henry, Historia rozłamu Kościoła Wschodniego i Zachodniego, Wydawnictwo WAM, Kraków, 2009.

Clayer Natalie, The Dimension of Confessionalisation in the Ottoman Balkans at the Time of Nationalisms, w: Conflicting Loyalties in the Balkans. The Great Powers, the Ottoman Empire, and Nation-Building, ed. Hannes Grandits, Natalie Clayer, Robert Pichler, I.B. Tauris, London, 2011, s. 89-109.

92 „България“, r. 1, nr 27, 25.09.1859, s. 1.

93 „България“", r. 1, nr 23, 29.08.1859, s. 3. 
Clogg Richard, Historia Grecji nowożytnej, Książka i Wiedza, Warszawa 2006.

Cybart Natalia, Nieznana historia Bułgarii pióra krakowskiego jezuity Józefa Holubowicza, w: Nowe spojrzenie na kulturę butgarska, red. Diana Ivanowa, Tadeusz Lewaszkiewicz, Natalia Reczek, Katedra Filologii Słowiańskiej UAM, Poznań, 2008, s. 24-41.

Czekalski Tadeusz, Kościót prawosławny w życiu politycznym nowożytnego państwa greckiego, w: Religijna mozaika Bałkanów, red. Mariola Walczak-Mikołajczakowa, Collegium Europaeum Gnesnense, Gniezno, 2008, s. 145-151.

Dąbek-Wirgowa Teresa, Historia literatury bułgarskiej, Ossolineum, Wrocław, 1980.

Gałązka Wojciech (red.), Naród i kultura. Antologia esejów i artykułów o narodzie i kulturze bułgarskiej, Uniwersytet Jagielloński, Kraków, 1985.

Göçek Fatma Muge, Ethnic Segmentation, Western Education, and Political Outcomes: Nineteenth-Century Ottoman Society, „Poetics Today”, 14, 1993, 3, s. 507-538.

Grzegorzewski Jan, Rok przewrotów. Bułgarya 1885-1886, Lwów, 1900.

Jezernik Božidar, Dzika Europa. Bałkany w oczach zachodnich podróżników, Universitas, Kraków, 2007.

Jóźwiak Wojciech, Piśmiennictwo polskiej misji unickiej na terenie Bułgarii w drugiej połowie XIX wieku, Alleluja - Wydawnictwo Zmartwychwstańców, Kraków, 2008.

Jóźwiak Wojciech, Święci Cyryl i Metody w koncepcji unitów bułgarskich, w: Święci w kulturze i duchowości dawnej i współczesnej Europy, red. Wanda Stępniak-Minczewa, Zdzisław Kijas, PAT, Kraków 1999 , s. $145-154$.

Kajsiewicz Hieronim, O unii butgarskiej. Rys historyczny, Paryż, 1863.

Klejn Zbigniew, Próby stworzenia polskich przyczótków militarno-politycznych na Bałkanach w XIX w., „Studia z Dziejów Rosji i Europy Środkowo-Wschodniej”, 40, 2005, s. 5-24.

Minczew Georgi, ,Watykańscy szpiedzy” i zdrajcy narodu w XIX wieku w Butgarii, w: Obraz zdrajcy i szpiega w kulturach stowiańskich, red. Teresa Dąbek-Wirgowa, Andrzej Makowiecki, Antyk, Warszawa, 1999.

Naumow Aleksander, Ksenofobia i nieufność jako mechanizmy wspótżycia chrześcijan, w: Chrześcijański Wschód i Zachód. Formy dialogu, wzory kultury, kody pamięci, red. Wojciech Jóźwiak, Izabela LisWielgosz, Wydawnictwo „Pro”, Poznań, 2012, s. 87-97.

Nowosad Andrzej, Władza i media w Bułgarii, WUJ, Kraków 2008.

Popek Krzysztof, „Idea zrodzona z rozpaczy“. Rola ruchu unickiego w butgarskim odrodzeniu narodowym, „Balcanica Posnaniensia. Acta et studia”, 21, 2014, s. 103-120.

Popek Krzysztof, „Mała kwestia wschodnia”. Aspekty polityczne dziewiętnastowiecznego bułgarskiego ruchu cerkiewnego, ,Studenckie Zeszyty Naukowe Instytutu Filologii Słowiańskiej UJ”, 3, 2013, 1, s. 73-88.

Price Roger, Napoleon III and the Second Empire, Taylor \& Francis, New York, 1997.

Rusin Bartłomiej, Kryzys Imperium Osmańskiego w świetle bułgarskiej publicystyki odrodzeniowej (przypadek Christo Botewa, Lubena Karawełowa i Georgiego Rakowskiego), „Studenckie Zeszyty Naukowe Instytutu Filologii Słowiańskiej UJ”, 3, 2013, 1, s. 89-106.

Simeonova-Konach Galia, ,Pascha Bułgarska“, Unia i jej konteksty konstantynopolitańskie w badaniach prof. Tonczo Żeczewa, w: Chrześcijański Wschód i Zachód. Formy dialogu, wzory kultury, kody pamięci, red. Wojciech Jóźwiak, Izabela Lis-Wielgosz, Wydawnictwo „Pro”, Poznań, 2012, s. 33-51.

Skowronek Jerzy, Polacy jako partnerzy polityczni na Bałkanach w latach trzydziestych-pięćdziesiatych XIX w., w: Wielka Emigracja i sprawa polska a Europa (1832-1864), red. Sławomir Kalembka, Wydawnictwo UAM, Toruń, 1971, s. 89-105.

Skowronek Jerzy, Sprzymierzeńcy narodów batkańskich, PWN, Warszawa, 1983.

Skowronek Jerzy, Tanty Mieczysław, Wasilewski Tadeusz, Historia Stowian południowych i zachodnich, PWN, Warszawa, 1988.

Sprawa butgarska, cz. 2 (przedruk z „Tygodnika Katolickiego”), Grodzisk, 1862.

Sprawozdanie Missyi Bułgarsko-katolickiej O.O. Zmartwychwstańców w Adrianopolu za rok szkolny 1878/1879, Adrianopol, 12.12.1879, Biblioteka xx. Czartoryskich, rkps nr 6748 III. 
Stafford Poole, Eugène Boré and the Bulgarian Catholic Movement, „Vincentian Heritage Journal“, 16, 1996, 2, s. 193-208.

Stamatopoulos Dimitrios, From Millets to Minorities in the 19th Century Ottoman Empire: an Ambiguous Modernization, w: Citizenship in Historical Perspective, red. Steve Ellis, Guðmundur Hálfadanarson, Ann Isaacs, Pisa University Press, Piza, 2006, s. 253-273.

Stępniak-Minczewa Wanda, I francescani in Bulgaria. Blasius Kleiner: un francescano in viaggio per i Balcani (sulla base della «Storia della Bulgaria» din Blasius Kleiner), w: I francescani nella storia dei popoli balcanici, ed. Viviana Nosilia, Marco Scarpa, Centro interdipartimentale di studi balcanici e internazionali, Genua 2011, s. 59-68.

Todorova Maria, Bałkany wyobrażone, Wydawnictwo Czarne, Wołowiec, 2008.

Traikov Vesselin, Georgi Rakovski A Short Biography, Sofia Press, Sofia, 1977.

Wasilewski Tadeusz, Historia Bułgarii, Ossolineum, Wrocław, 1970.

Widerszal Ludwik, Butgarski ruch narodowy 1856-1872, Towarzystwo Naukowe Warszawskie, Warszawa, 1937.

Zowczak Magdalena, Biblia ludowa. Interpretacje wątków biblijnych w kulturze ludowej, Wydawnictwo UMK, Toruń, 2013.

Ангелов Борис, Дебатът Славейков - Вазов, или идеологът на „Мисъл” срещу идеолога на нацията, Литературен клуб, Шумен, 1996.

Бонева Вера, Българското иърковнонационално движение 1856-1870, За буквите, София, 2010.

„България“, Цариград, 1859-1861.

„Гайда”, Цариград, 1864.

Генчев Николай, Българската култура $X V-X I X$ в., УИ „Климент Охридски”, София, 1988.

Генчев Николай, Българското Възраждане, Издателска къща „Иван Вазов“, София, 1995.

Детрез Раймонд, „Туриите със сила, гъриите с книга “. Митът за двойното робство, „Либерален преглед", 2012, 2, s. 454-470.

Динеков Петър (ред.), Възрожденски страници. Антология, т. 1, Български писател, София, 1969.

Данова Надя, Образи на гъричи и западноевропейцฺи в българската книжнина през XVIII-XIX век, „Либерален преглед”, 2014, 3, s. 888-922.

Догматические послания православных иерархов XVII-XIX веков о православной вере, Свято-Тройская Сергиева Лавр, 1995.

Друмев Васил, Нещастна фамилия. Ученик и благодател, Български писател, София 1989.

„Дунавски лебед“, Белград, 1860-1861.

Елдъров Светлозар, Католииите в България (1878-1989). Историческо изследване, Международен център за изследване на малцинствата и културните взаимодействия в България, София, 2002.

Жечев Тончо, Българският Великден или страстите български, Издателство „Захари Стоянов“, София, 2007.

Иванчев Димитър (ред.), Български периодичен печат 1844-1944, т. 1, Наука и изкуство, София, 1966.

Игов Светлозар, История на българската литература, Циела, София, 2002.

Иречек Константин, История на българите: с поправки и добавки от самия автор, Наука и изкуство, София, 1978.

Каравелов Любен, Съчинения, т. 7, Русе, 1887.

Ковачева Маргарита, Драган Цанков: общественик, политик, дипломат до 1878, Наука и изкуство, София, 1982.

Леков Дочо (ред.), Българска възрожденска драма, Библиотека за ученика, София 1973.

Маркова Зина, Българското иърковно-национално движение до Кримската война, БАН, София, 1976.

Минчев Георги, Богословът Георги Сава Раковски: Отговор Чокърляну - една (по)забравена брошура на комплексия войвода, w: Wielkie mity narodowe Stowian, red. Anna Gawarecka, Aleksander 
Naumow, Bogusław Zieliński, Uniwersytet im. Adama Mickiewicza w Poznaniu, Poznań, 1999, s. $149-163$.

Николова Веска, Саздов Димитър (ред.), Програми, програмни документи и устави на бържоазните партии в България 1879-1918, Наука и изкуство, София, 1992.

Патриарх Кирил, Принос към униатството в Македония след Освободителната война (18791895), Синодално издателство, София, 1968.

Пейков Стефан, Забравените кметове на Бургас: Димитър Тодоров Бракалов, www.morskivestnik. com/mor_kolekcii/kmetowe/zabrkmbsdim.html [dostęp: 12. 12. 2105].

Раковски Георги Сава, Отговор Чокърляну. Доказаящ че Въсточная иърква е истинно православна, w: Wielkie mity narodowe Stowian, red. Anna Gawarecka, Aleksander Naumow, Bogusław Zieliński, Uniwersytet im. Adama Mickiewicza w Poznaniu, Poznań, 1999, s. 125-148.

Раковски Георги Сава, Преселение в Русия или руската убийствена политика за българите, София, 1861.

Раковски Георги Сава, Съчинения, т. 2: Публицистика, Български писател, София, 1983.

Смоховска-Петрова Ванда, Неофит Бозвели и българският иърковен въпрос. Нови данни из архивите на Адам Чарториски, БАН, София, 1964.

Снегаров Иван, История на Охридската Архиепископия, т. 1: От основаването ѝ до завладяването на Балканския полуостров от туриите, „М. Дринов“, София, 1995.

Снегаров Иван, История на Охридската Архиепископия, t. 2: От падането под туриите до нейното унищожение, „М. Дринов“, София, 1995.

Тодев Илия, Батак 1876 - мит или история. Текстове по Българско Възраждане, Тангра ТанНакРа, София, 2010.

Узунова Мария, Драган Цанков - неспокоен дух на границата на две епохи, „LiterNet”, 100, 2008, 3, http://liternet.bg/publish22/m_uzunova/dr_cankov.htm.

Чилингиров Стилиян, Драган Цанков, w: Български писатели. Живот-творчество-идеи, т. 2, ред. Михаил Апнаудов, Факел, София, 1929, s. 174-193. 
